\title{
CLINICAL AND EPIDEMIOLOGICAL FEATURES OF DEFINITIVE AND PRESUMED LOXOSCELISM IN SÃO PAULO, BRAZIL
}

\author{
Ceila Maria Sant'Ana MÁLAQUE, Jaime Enrique CASTRO-VALENCIA, João Luiz Costa CARDOSO, Francisco Oscar de Siqueira FRANÇA,
} Kátia Cristina BARBARO \& Hui Wen FAN

\begin{abstract}
SUMMARY
A retrospective study analysed 359 proven or presume cases of loxoscelism seen at the Hospital Vital Brazil, Instituto Butantan, São Paulo, Brazil, between 1985 and 1996. The spider was identified in 14\%. The bites occurred predominantly in the urban areas (73\%) between September and February. Patients > 14 years were commonest inflicted (92\%) and $41 \%$ were bitten while getting dressed. Only $11 \%$ sought medical care within the first 12 hours post bite.

Cutaneous loxoscelism was the commonest form presenting (96\%); commonest manifestations were: pain (76\%), erythema (72\%), edema with enduration (66\%), ecchymosis (39\%). Skin necrosis occurred in 53\% of patients, most frequently seen on trunk, tigh and upper arm, and when patients seek medical care more than 72 hours after bite. Local infection was detected in 12 patients (3\%). Hemolysis was confirmed in 4 cases (1.1\%). Generalised cutaneous rash, fever and headache were also observed in $48 \%$ of the total of patients. None of them had acute renal failure or died. Treatment usually involved antivenom administration (66\%), being associated with corticosteroids (47\%) or dapsone (30\%). Presumptive diagnosis of loxoscelism may be established based on clinical and epidemiological findings. Further investigations are required to prove the value of antivenom and other treatment schedules.
\end{abstract}

KEYWORDS: Spider bite; Loxosceles; Dermonecrosis; Envenoming; Loxoscelism.

\section{INTRODUCTION}

Loxosceles genus includes several different spider species and represents an important cause of necrotic arachnidism. The brown spider (vulgar name) may range in length from $1-5 \mathrm{~cm}$ leg to leg, fawn to dark brown in color, and has on its dorsal cephalotorax a fiddle-shapped dark brown marking. There is no evidence that the spider is aggressive; on the contrary, the animal is retiring and prefers living in dark areas. The spider has extended its habitat to include homes, garages, and barns, where encounters with humans are more likely. In Brazil, three species have been mostly implicated in human envenoming: L. gaucho, L. laeta and L. intermedia ${ }^{17}$.

Necrotic and viscerocutaneous arachnidism in consequence of Loxosceles spider bite (loxoscelism) has been reported in South America $^{6,18,26,27,28}$, North America ${ }^{2,11,15,24}$, Southern Africa ${ }^{19,20}$ and Israel ${ }^{5}$. There are no reports of loxoscelism in Australia, but it is likely that many cases of necrotic arachnidism would be caused by Loxosceles spiders $^{35}$. In Brazil, between 1990 and 1993, more than 6,500 human accidents had been attributed to Loxosceles spp, corresponding to $37 \%$ of poisonous spider bites in Brazil, most of cases registered in the South region $(95 \%)$, followed by the Southeast $(4 \%)^{6}$. The loxoscelism is particularly prominent in the metropolitan area of Curitiba, Paraná State, which accounts for about 2,000 cases per year (unpublished data).

Loxoscelism is notorious for producing a necrotic skin ulcer that heals slowly and may require surgical excision or skin grafting. Systemic involvement (viscerocutaneous form) is much less common and is the cause of the rare deaths, usually associated with acute renal failure and disseminated intravascular coagulation due to intravascular hemolysis ${ }^{27,28}$. The mechanisms involved in the pathophysiology of Loxosceles envenoming are complex. Venom is rich in many enzymes such as hydrolases, hyalurodinase, lipases, peptidases, collagenases, alkalin phosphatase, 5-ribonucleotidase, phosphohydrolases, proteases ${ }^{13,15,22,23}$. A key component for the dermonecrotic lesion appears to be sphyngomyelinase $\mathrm{D}$, that interacts with the cellular membrane, unchains reactions involving components of the complement system, platelets, and polymorphonuclear leukocytes ${ }^{15,29,33}$. Sphyngomyelinase D activity was also proved to be responsible for the intravascular hemolysis ${ }^{14}$, which is mediated by the complement system ${ }^{30,31}$, and secondary to activation of endogenous metalloproteases ${ }^{32}$.

Diagnosis of loxoscelism is rarely based on the identification of the spider. Unless the patient catches the animal and brings it in for formal

Instituto Butantan, Av. Vital Brasil 1500, 05503-900 São Paulo, SP, Brazil

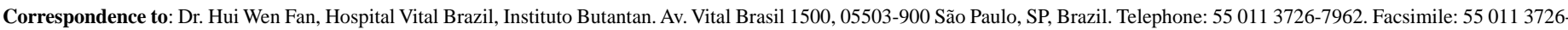
1505.email: fhui@uol.com.br 


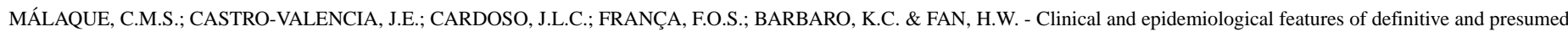
loxoscelism in São Paulo, Brazil. Rev. Inst. Med. trop. S. Paulo, 44(3):139-143, 2002.

identification, the diagnosis is only presumptive, based solely on clinical signs and symptoms. In the early stages, cutaneous loxoscelism may be misdiagnosed as cellulitis or an insect sting. Although incipient laboratory tests have been perfomed ${ }^{8,9}$, no definitive immunodiagnosis is yet available.

Most of published reports of Loxosceles spider bites are of individual cases or of limited series. In contrast, our objective was to describe a long term historical series of definite and presume loxoscelism, in order to define clinical and epidemiological features that may be of fundamental importance to the diagnosis.

\section{PATIENTS AND METHODS}

A retrospective study was made by reviewing the records of patients with definite or presume loxoscelism who had been referred to the Hospital Vital Brazil (HVB), Instituto Butantan, São Paulo, Brazil, between January 1985 to December 1996. Instituto Butantan is a venom research centre, has a antivenom production division, and a health service specialized in the treatment of patients bitten by venomous animals. We selected cases in which suggestive clinical manifestations of Loxosceles envenoming were present, whether the spider was identified or not. Epidemiological and clinical information, such as date of bite, type of activity concurrently undertaken when patient was bitten, time elapsed until presentation to hospital, location and appearance of lesion upon admission, systemic effects, treatment administered and outcome, were recorded. Cutaneous loxoscelism was defined as a combination of skin puncture lesion, usually with an eccentric serous or hemorrhagic blistering and ecchymosis, surrounded by an irregular pale area, that could not be attributable to any other dermatological lesion, usually present in the first 2-3 days after bite. In cases where patients were seen later, the initial lesion might had evolved to an area of central necrosis, with a sharply-defined ulceration rim and a base of granulation tissue. Viscerocutaneous loxoscelism was defined when intravascular hemolysis was suspected, irrespective of severity of the local reaction. If the agent was brought by the patient or relatives, the identification of the specimen had been made by a arachnologist and a definite diagnosis of loxoscelism was made; otherwise, presume loxoscelism was considered. Heterologous specific Loxosceles or polyvalent antivenom (for Loxosceles sp, Phoneutria sp and Tityus sp) was given to those patients who had not necrotic ulcer on admission. All antivenoms were (Fab') immunoglobulins produced by Instituto Butantan and dispensed in $5 \mathrm{ml}$ vial, each ml neutralizing 15 minimal necrotizing dose of L. gaucho venom. Antivenom was given intravenously and the amount varied according to envenoming severity. Prednisone $(40-60 \mathrm{mg} / \mathrm{d}$ for 5 to 7 days) and dapsone (100 mg/d for 7 days) were occasionally administered in a tentative to reduce the inflammatory reaction. Intravascular hemolysis was suspected when jaundice was present and confirmed if one of the following laboratorial tests was altered: hemoglobin $(\mathrm{Hb})<11.0 / 13.0 \mathrm{~g} / \mathrm{dL}$ (female/male), packed cell volume $(\mathrm{PCV})<37 / 40 \%$ (female/male), total bilirubin $(\mathrm{TB})>1.0 \mathrm{mg} / \mathrm{dL}$, or indirect bilirubin $(\mathrm{IB})>0.6 \mathrm{mg} / \mathrm{dL}$.

A database of this pooled information was constructed and frequency distribution of the variables were obtained using the Epi-Info 6.04 software. The chi-square test was used to compare proportions and statistical significance was considered when $\mathrm{p}<0.05$.

\section{RESULTS}

Three hundred and fifty-nine records were analysed, with a mean of 30 cases per year. Most of the bites occurred in urban areas (73\%), season variation cases occurred predominantly between September and February, which corresponds to Spring and Summer in Southern Brazil (Fig. 1). No gender difference was observed: $52 \%$ out the patients were male and $48 \%$ were female $(\mathrm{p}=0.49)$. The minority of bites $(7 \%)$ occurred in patients under 15 years old (mean age $=34.7 \pm 15.4$ years old; median $=$ 34). The interval between the time of the bite and presentation to hospital was usually more than 12 hours $(90 \%)$, almost half of the patients sought medical care 2 days after of the bite. The most affected anatomical areas were thigh and trunk (Table 1), reflecting the circumstances of the bite event. Most patients (93\%) had a history of spider bite and accidents occurred more frequently while dressing $(42 \%)$ or sleeping $(18 \%)$. The causal spider was brought by 51 patients (14\%), 28 being classified as L. gaucho, 5 as L. laeta and 18 as Loxosceles sp (species unascertainable).

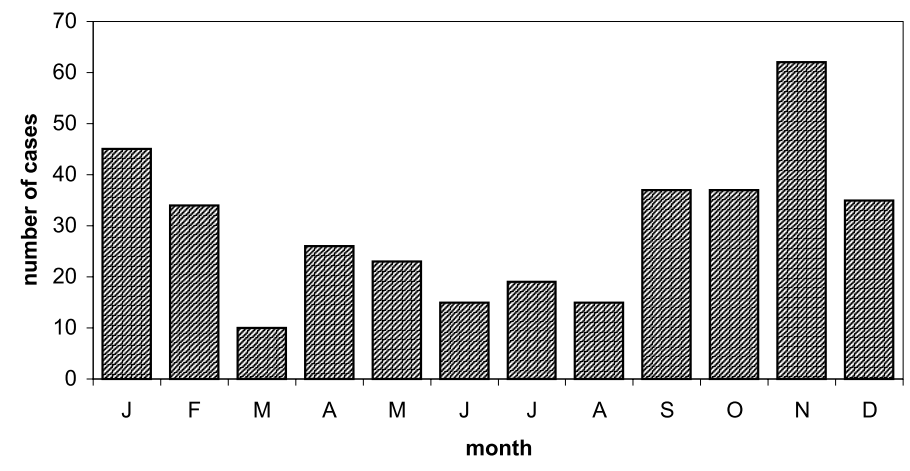

Fig. 1 - Monthly distribution of loxoscelism. Hospital Vital Brazil (HVB), Instituto Butantan, 1985-1996.

The predominant clinical features were related to cutaneous loxoscelism (96.4\%). On admission pain, erythema, oedema with induration, and ecchymosis were frequently seen (Table 2). Necrotic lesion that dropped off leaving an ulcer was observed in 191 patients (53\%), being 122 on admission, and 69 after antivenom therapy. Necrosis was more frequently observed when the bite occurred in proximal anatomic areas, such as trunk, thigh and upper arm $(\mathrm{p}=0.0002)$ and in those patients who arrived at the hospital 72 hours or more after the accident ( $\mathrm{p}<0.0001)$. In the follow-up period, which varied from one to eight weeks, mild local infection was detected in 12 patients (3\%), and healing with scar in $15(4 \%)$.

Viscerocutaneous loxoscelism was suspected in 13 patients that presented jaundice on admission or in the subsequent days after hospitalization. Of these, laboratory tests showed decrease of hematological parameters in 4 cases (Table 3). In one case, data was not available since patient was transferred to the referral hospital. Agent was not brought for identification in none of the viscerocutaneous cases therefore relation between severity and Loxosceles species was not established. Unspecific symptoms were evident in 172 patients (48\%), either cutaneous or viscerocutaneous loxoscelism, but were commoner in the latter form. Itching morbilliform or scarlatiniform skin eruption 
Table 1

Epidemiological features of loxoscelism in 359 patients. Hospital Vital Brazil, 1985-1996

\begin{tabular}{lrr}
\hline Age (years) & $\mathrm{N}$ & $\%$ \\
\hline Under 15 & 25 & 7 \\
$15-29$ & 120 & 33 \\
$30-44$ & 122 & 34 \\
$45-59$ & 68 & 19 \\
60 or more & 21 & 6 \\
Unknown & 3 & 1 \\
\hline Interval between accident and presentation to hospital & $\mathrm{N}$ & $\%$ \\
\hline 12 hours & 38 & 10 \\
12-24 hours & 83 & 23 \\
1-2 days & 65 & 18 \\
2-3 days & 53 & 15 \\
3-4 days & 39 & 11 \\
$\geq 4$ days & 81 & 23 \\
\hline Site of bite & $\mathrm{N}$ & $\%$ \\
\hline Trunk & 56 & 16 \\
Upper arm & 54 & 15 \\
Thigh & 124 & 34 \\
Other & 124 & 34 \\
Not recorded & 1 & 0 \\
\hline
\end{tabular}

Table 2

Local signs and symptoms of loxoscelism in 359 patients on admission at Hospital Vital Brazil, 1985-1996

\begin{tabular}{lrr}
\hline Local symptomatology & Frequency & $\%$ \\
\hline Pain & 274 & 76 \\
Erythema & 259 & 72 \\
Edema + induration & 236 & 66 \\
Ecchymosis & 139 & 39 \\
Necrosis & 122 & 34 \\
Blister & 51 & 14 \\
\hline
\end{tabular}

was observed in $32 \%$, low grade fever $\left(37.5-38.5^{\circ} \mathrm{C}\right)$ in $16 \%$ and headache in $10 \%$ of the total number of patients, which disappeared in the first three days.

Regarding to the treatment schedules, 237 patients $(66 \%)$ received 5 to $75 \mathrm{ml}$ of specific antivenom ( mean $=28 \pm 13.5 \mathrm{ml}$ ); of these, antivenom was combined with corticosteroid in $47 \%$, and with dapsone in $30 \%$. Early anaphylactic reactions, mostly mild (urticaria and nausea) and not life threating, were observed in $20 \%$. No acute renal failure, disseminated intravascular coagulation or death were registered.

\section{DISCUSSION}

Loxosceles spider bite is a well-documented cause of dermonecrotic lesion in humans. This study describes a retrospective analysis of a large series of loxoscelism from São Paulo metropolitan area (São Paulo State, Brazil). We conclude that loxoscelism could be even more common that we observed due to the absence of a specific diagnostic test and the fact of the spider is not usually captured and identified.

Many of the characteristics presented herein are similar to those reported elsewhere for patients bitten by Loxosceles spiders: most patients fell within age range from 15 to 59 years, were equally distributed by gender, most bites occurred during warm seasons, and the most frequent site of bite was the thigh and trunk ${ }^{27,28}$. Interestingly, $93 \%$ could give a history of spider bite, in contrast with other authors' observations ${ }^{7,34}$ that referred that most accidents go unnoticed until the appearance of a local lesion. Of the 51 spiders that had been brought and identified, the most prevalent species was L. gaucho. Other studies in Brazil and elsewhere implicate a variety of species, such as $L$. intermedia ${ }^{25}, L$. laeta $a^{27,28,37}, L$. reclusa ${ }^{24}$, and L. rufescens ${ }^{5,34}$. Experimentally, different Loxosceles venoms are associated with varying degrees of toxicity ${ }^{3,35}$ and may reflect differences in clinical presentation and severity of envenoming.

The diagnosis of loxoscelism is rarely based on absolute identification on the spider and patients are usually bitten while sleeping or dressing. Usually a specimen of Loxosceles is found in the bedclothes adjacent to the bite area on awakening from sleep. Since the bite is relatively painless, some patients may even be not aware that a spider bite has occurred and

Table 3

Viscerocutaneous loxoscelism in 12 patients. Hospital Vital Brazil, 1985-1996

\begin{tabular}{|c|c|c|c|c|c|}
\hline No. & Age (years) & Sex & Interval between bite and jaundice & $\mathrm{Hb} / \mathrm{PCV}^{*}$ & Total bilirubin / indirect bilirubin \\
\hline 1 & 3 & M & $\cong 16 \mathrm{~h}$ & $5.0 / 10$ & - \\
\hline 2 & 33 & M & 3 days & $15.5 / 43$ & $2.9 / 2.5$ \\
\hline 3 & 16 & $\mathrm{~F}$ & 2 days & $7.9 / 21$ & $3.2 / 2.9$ \\
\hline 4 & 41 & M & 2 days & $-1-$ & $2.4 / 1.9$ \\
\hline 5 & 17 & $\mathrm{~F}$ & 10 days & $6.1 / 19$ & $-1-$ \\
\hline 6 & 29 & $\mathrm{M}$ & 5 days & $13.6 / 37$ & $2.0 / 1.3$ \\
\hline 7 & 37 & $\mathrm{~F}$ & 13 days & $12.4 / 37$ & $3.9 / 1.8$ \\
\hline 8 & 42 & $\mathrm{~F}$ & 3 days & $13.6 / 40$ & $2.6 / 1.7$ \\
\hline 9 & 22 & $\mathrm{M}$ & 2 days & $-1-$ & $3.7 / 3.0$ \\
\hline 10 & 46 & $\mathrm{~F}$ & 7 days & $-1-$ & $3.5 / 2.4$ \\
\hline 11 & 33 & $\mathrm{~F}$ & 2 days & $4.4 /-$ & $2.1 / 1.6$ \\
\hline 12 & 15 & $\mathrm{M}$ & 2 days & $-1-$ & $3.7 / 3.0$ \\
\hline
\end{tabular}

* Hb: hemoglobin; PCV: packed cell volume; 1 record not available 


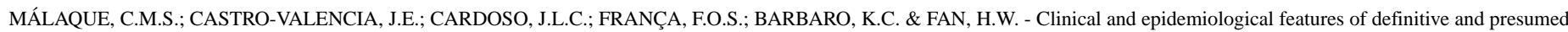
loxoscelism in São Paulo, Brazil. Rev. Inst. Med. trop. S. Paulo, 44(3):139-143, 2002.

fang marks are seldom visible. There is frequently a transitory stinging at the time of the bite and mild or severe reaction begins after some hours. One of the difficulties making the correct diagnosis is the fact that, in early stages, the lesion does not present clearly defined aspects but may be mistaken for cellulitis or insect bites.

The local reaction of the brown spider bite described here varied considerably, from mild pain and erythema to extensive skin necrosis with ulceration. In most of our cases, diagnosis was made in the presence of painful edema with enduration and ecchymosis, surrounded by a livid area, that progressed slowly, associated with a history of spider bite. In those with a large and deep necrosis, ulceration lasted several months before healing. Even in the presence of necrotic lesion, local infection was not so common; all were treated with oral antibiotics, and had no systemic complications. Besides the cutaneous lesion, unspecific manifestations, such as fever, headache, and a generalized, pruritic, morbilliform or scarlatiniform rash may occur in the first 24 to 48 hours post bite. Although not present in all of our patients, the presence of these unspecific clinical features assisted in making the diagnosis of loxoscelism.

Viscerocutaneous loxoscelism is relatively uncommon and may have a course independent of the local reaction. The frequency of this form observed in our study was lower than has been reported by other authors ${ }^{27,28}$. Some spider factors are speculated to be associated with poorer bite outcome, such as $\mathrm{sex}^{21}$, ontogenetic variations ${ }^{1}$ and species $^{28}$. In Santa Catarina State, Brazil, where L. laeta is frequently found, hemolysis was described in $13 \%{ }^{28}$; a similar proportion of viscerocutaneous form were found in Chile, where L. laeta is also a prevalent species $^{27}$. Certain characteristics of the patient, such as age ${ }^{15}$ and genetic variations ${ }^{4}$ may also be implicated in the severity of envenomation. In some of our patients, jaundice was observed more than one week after bite, which highlights for the possibility of late hemolysis, not impaired by antivenom. This fact contrast with other studies in which hemolytic anemia was observed up to the third day after bite ${ }^{15,34,35}$, and suggests the participation of endogenous mediators in the generation of systemic alterations, as demonstrated experimentally ${ }^{32}$.

A great deal of controversy exists regarding the value of drugs and antivenom in the treatment of loxoscelism ${ }^{23,36,37}$. In our study, $19 \%$ of patients develop necrosis despite being treated with antivenom. Although skin necrosis was therefore not prevented, we cannot conclude that antivenom is totally inefficient to reduce the extend of dermatological lesion. In this way, antivenom is routinely given, in our hospital, in patients in which necrosis is still not present. The proportion of early anaphylactic reactions was not exceptionally high and similar to that observed for other antivenoms ${ }^{10,12}$, and manifestations were promptly reversed by proper measures.

In parallel, drugs with anti-inflammatory activities, such as dapsone and corticosteroids, have also been used in an attempt to reduce the extension of necrosis. The efficacy of dapsone in the treatment of skin diseases in which polymorphonuclear leucocytes play a prominent role is the rationale for its using in Loxosceles spider bite. Apparently a mild reduction of the cutaneous lesion was observed in patients that used high doses of prednisone in a short term schedule. On the other hand, dapsone seemed to not alter the progression of the dermonecrosis, which contrasts with some reports of an apparent effectiveness of this drug in reducing the extent of skin damage ${ }^{16,24}$. However, no controlled clinical trials have been conducted and the best therapeutic schedule in the treatment of loxoscelism is still to be defined. Furthermore, the effectiveness of either treatment depends on the time between bite and medical assistance.

In conclusion, loxoscelism produces a highly suggestive picture, and the sum of clinical and epidemiological findings may establish the diagnosis, even if the spider is not captured and identified.

\section{RESUMO}

\section{Aspectos clínicos e epidemiológicos do loxoscelismo em São Paulo, Brasil}

Foram analisados, em um estudo retrospectivo, 359 casos de loxoscelismo comprovados ou presumidos, acompanhados no Hospital Vital Brazil, Instituto Butantan, São Paulo, Brasil, entre 1985 e 1996. A aranha foi identificada em $14 \%$ dos casos. Os acidentes predominaram nas áreas urbanas (73\%), entre setembro e fevereiro. Pacientes maiores de 14 anos foram mais freqüentemente atingidos (92\%) e $41 \%$ foram picados ao se vestir. Apenas $11 \%$ procuraram o serviço médico nas primeiras horas após a picada.

A forma cutânea foi a mais freqüente (96\%), sendo as principais manifestações descritas: dor (76\%), eritema (72\%), edema com enduração (66\%), equimose (39\%). Necrose cutânea ocorreu em 53\% dos pacientes, sendo mais freqüentemente observada no tronco, coxa e braço, e naqueles que procuraram atendimento médico mais de 72 horas após o acidente. Infecção local foi detectada em 12 pacientes (3\%). A hemólise foi confirmada em 4 casos $(1,1 \%)$. Exantema generalizado, febre e cefaléia foram observados em $48 \%$ dos pacientes. Não se verificou insuficiência renal ou óbito. O antiveneno foi administrado em $66 \%$ dos casos, associado a corticosteróide em $47 \%$ ou a dapsona em $30 \%$. O diagnóstico presuntivo de loxoscelismo pode ser estabelecido baseado em achados clínicos e epidemiológicos. Maiores investigações são necessárias para se comprovar o valor do antiveneno e outras drogas.

\section{ACKNOWLEDGEMENTS}

The authors thank ML Santoro and K Winkel for thoughtful manuscript revision.

\section{REFERENCES}

1. ANDRADE, R.M.G.; OLIVEIRA, K.C.; GIUSTI, A.L.; SILVA, W.D. \& TAMBOURGI, D.V. - Ontogenetic development of Loxosceles intermedia spider venom. Toxicon, 37: 627-632, 1999.

2. ATKINS, J.A.; WINGO, C.W.; SODEMAN, W.A. \& FLYNN, J.E. - Necrotic arachnidism. Amer. J. trop. Med. Hyg., 7: 165-184, 1958.

3. BARBARO, K.C.; FERREIRA, M.L.; CARDOSO, D.F.; EICKSTEDT, V.R.D. \& MOTA, I. - Identification and neutralization of biological activities in the venoms of Loxosceles spiders. Braz. J. med. biol. Res., 29: 1491-1497, 1996.

4. BARRETO, O.C.O.; CARDOSO, J.L.C. \& de CILLO, D. - Viscerocutaneous form of loxoscelism and erythrocyte glucose-6-phosphate deficiency. Rev. Inst. Med. trop. S. Paulo, 27: 264-267, 1985. 
5. BORKAN, J.; GROSS, E.; LUBIN, Y. \& ORYAN, I. - An outbreak of venomous spider bites in a citrus grove. Amer. J. trop. Med. Hyg., 52: 228-230, 1995.

6. BRASIL. MINISTÉRIO DA SAÚDE - Manual de diagnóstico e tratamento de acidentes por animais peçonhentos. Brasília, Fundação Nacional de Saúde, 1998.

7. BURNETT, J.W.; CALTON, G.J. \& MORGAN, R.J. - Brown recluse spider. Cutis, 36: 197-198, 1985.

8. CARDOSO, J.L.C.; FAN, H.W.; FRANÇA, F.O.S.; WARRELL, D.A. \& THEAKSTON, R.D.G. - Detection by enzyme immunoassay of Loxosceles gaucho venom in necrotic skin lesions caused by spider bites in Brazil. Trans. roy. Soc. trop. Med. Hyg., 84: 608-609, 1990.

9. CHÁVEZ-OLÓRTEGUI, C.; ZANETTI, V.C.; FERREIRA MINOZZO, J.C. et al. ELISA for the detection of venom antigens in experimental and clinical envenoming by Loxosceles intermedia spiders. Toxicon, 36: 563-569, 1998.

10. CUPO, P.; AZEVEDO-MARQUES, M.M.; MENEZES, J.B. \& HERING, S.E. - Reações de hipersensibilidade imediatas após uso intravenoso de soros antivenenos: valor prognóstico dos testes de sensibilidade intradérmicos. Rev. Inst. Med. trop. S. Paulo, 33: $115-122,1991$

11. ESCALANTE-GALINDO, P.; MONTOYA-CABRERA, M.A.; TERROBA-LARIOS, V.M.; NAVA-JUÁREZ, A.R. \& ESCALANTE-FLORES, I. - Local dermonecrotic loxoscelism in children bitten by the spider Loxosceles reclusa (the "violin" spider). Gac. med. Mex., 135: 423-426, 1999.

12. FAN, H.W.; MARCOPITO, L.F.; CARDOSO, J.L.C. et al. - Sequential randomised and double blind trial of promethazine prophylaxis against early anaphylactic reactions to antivenom for Bothrops snake bites. Brit. med. J., 318: 1451-1452, 1999.

13. FEITOSA, L.; GREMSKI, W.; VEIGA, S.S. et al. - Detection and characterization of metalloproteinases with gelatinolytic, fibronectinolytic and fibrinogenolytic activities in brown spider (Loxosceles intermedia) venom. Toxicon, 36: 1039-1051, 1998.

14. FORRESTER, L.F.; BARRET, J.T. \& CAMPBEL, B.J. - Red blood cell lysis induced by the venom of the brown recluse spider. The role of sphingomyelinase D. Arch. Biochem. Biophys., 87: 355-356, 1978.

15. FUTRELL, J.M. - Loxoscelism. Amer. J. med. Sci., 304: 261-267, 1992.

16. KING Jr., L.E. \& REES, R.S. - Dapsone treatment of a brown recluse bite. J. Amer. med. Ass., 250: 648, 1983.

17. LUCAS, S. - Spiders in Brazil. Toxicon, 26: 759-772, 1988.

18. MACCHIAVELLO, A. - Cutaneous arachnidism or gangrenous spot of Chile. Puerto Rico J. Pub. Hlth. trop. Med., 22: 425, 1947.

19. NEWLANDS, G. \& ATKINSON, P. - Behavioural and epidemiological considerations pertaining to necrotic araneism in southern Africa. South Afr. med. J., 77: 92-95, 1990

20. NEWLANDS, G.; ISAACSON, C. \& MARTINDALE, C. - Loxoscelism in the Transvaal, South Africa. Trans. roy. Soc. trop. Med. Hyg., 76: 610-615, 1982.

21. OLIVEIRA, K.C.; ANDRADE, R.M.G.; GIUSTI, A.L.; SILVA, W.D. \& TAMBOURGI, D.V. - Sex-linked variation of Loxosceles intermedia spider venoms. Toxicon, 37: 217-221, 1999.

22. PORTARO, F.C.V.; MURAMATSU, D.; GUILHERME, P. \& BARBARO, K.C. - Presence of metalloproteases and serine-proteases in the Loxosceles gaucho crude venom. In: REUNIÃO ANUAL DA SOCIEDADE BRASILEIRA DE BIOQUÍMICA E BIOLOGIA MOLECULAR, 28., 1999.
23. REES, R.S.; ALTENBERN, D.P.; LYNCH, J.B. \& KING, L.E. - Brown recluse spider bites. A comparison of early surgical excision versus dapsone and delayed surgical excision. Ann. Surg., 20: 659-663, 1985

24. REES, R.S.; CAMPBELL, D.; RIEGER, E. \& KING Jr., L.E. - The diagnosis and treatment of brown recluse spider bites. Ann. Emerg. Med., 16: 945-949, 1987.

25. RIBEIRO, L.A.; EICKSTEDT, V.R.D.; RUBIO, G.B.G. et al. - Epidemiology of the accident for spiders of the gender Loxosceles Heinecken, Lowe in the State of Paraná (Brazil). Mem. Inst. Butantan, 55: 19-26, 1993.

26. ROSENFELD, G.; NAHAS, L.; de CILLO, D.M. \& FLEURY, C.T. - Envenenamentos por serpentes, aranhas e escorpiões. In: CINTRA DO PRADO, F. \& RIBEIRO DO VALLE, J., ed. Atualização terapêutica. Rio de Janeiro, Livraria Luso-Espanhola e Brasileira, 1957. p. 931-944.

27. SCHENONE, H.; SAAVEDRA, T.; ROJAS, A. \& VILLARROEL, F. - Loxoscelismo en Chile. Estudios epidemiológicos, clínicos y experimentales. Rev. Inst. Med. trop. S. Paulo, 31: 403-415, 1989.

28. SEZERINO, U.M.; ZANNIN, M.; COELHO, L.K. et al. - A clinical and epidemiological study of Loxosceles spider envenoming in Santa Catarina, Brazil. Trans. roy. Soc. trop. Med. Hyg., 92:, 546-548, 1998.

29. SMITH, C.W. \& MICKS, D.W. - The role of polymorphonuclear leukocytes in the lesion caused by the venom of brown spider, Loxosceles reclusa. Lab. Invest., 22: 90-93, 1970.

30. TAMBOURGI, D.V.; MAGNOLI, F.C.; EICKSTEDT, V.R.D. et al. - Incorporation of a 35-kilodalton purified protein from Loxosceles intermedia spider venom transforms human erythrocytes into activators of autologous complement alternative pathway. J. Immunol., 155: 4459-4466, 1995.

31. TAMBOURGI, D.V.; MAGNOLI, F.C.; van den BERG, C.W. et al. - Sphingomyelinases in the venom of the spider Loxosceles intermedia are responsible for both dermonecrosis and complement-dependent hemolysis. Bioch. Biophys. Res. Commun., 251: 366-373, 1998.

32. TAMBOURGI, D.V.; MORGAN, B.P.; DE ANDRADE, R.M. et al. - Loxosceles intermedia spider envenomation induces activation of an endogenous mettalloproteinase, resulting in cleavage of glycophorins from the erythrocyte surface and facilitating complement-mediated lysis. Blood, 95: 683-691, 2000.

33. VEIGA, S.S.; GREMSKI, W.; SANTOS, V.L.P. et al. - Oligosaccharide residues of Loxosceles intermedia (brown spider) venom proteins: dependence on glycosylation for dermonecrotic activity. Toxicon, 37: 587-607, 1999.

34. WASSERMAN, G.S. \& ANDERSON, P.C. - Loxoscelism and necrotic arachnism. J. Toxicol. clin. Toxicol., 21: 451-472, 1983-1984.

35. WHITE, J.; CARDOSO, J.L.C. \& FAN, H.W. - Clinical toxicology of spider bites. In: MEIER, J. \& WHITE, J., ed. Clinical toxicology of animal venoms and poisons. Boca Raton, CRC Press, 1995. p. 259-330.

36. WILSON, D.C. \& KING Jr., L.E. - Spiders and spider bites. Derm. Clin., 8: 277-286, 1990

37. ZAVAletA, A. - Loxoscelismo, un problema de salud en el Peru. Bol. Ofic. sanit. panamer., 103: 378-386, 1987.

Received: 14 September 2001

Accepted: 16 April 2002 